\section{Role of confounding factors in assessing immune competence of bivalves (Mya arenaria, Mytilus edulis) exposed to pollutants}

\author{
C. Brousseau-Fournier, ${ }^{1,2,3}$ G. Alix, $1,2,3$ \\ A. Beaudry, ${ }^{1,2,3}$ S. Gauthier-Clerc, ${ }^{4}$ \\ M. Duchemin, ${ }^{5}$ M. Fortier, ${ }^{2}$ M. Auffret, ${ }^{5}$ \\ Michel Fournier, ${ }^{1,2,3}$ P. Brousseau ${ }^{1,2,3}$ \\ 'Parc de la rivière Mitis, Ste-Flavie, \\ Quebec, Canada; 'Institut National de la \\ Recherche Scientifique-Institut-Armand- \\ Frappier (INRS-IAF), Laval, Quebec, \\ Canada; ${ }^{3}$ Université du Québec à \\ Rimouski, Rimouski, Quebec, Canada; \\ ${ }^{4}$ Institut des Sciences de la mer de \\ Rimouski (ISMER), Rimouski, Quebec, \\ Canada; ${ }^{5}$ Université de Bretagne \\ Occidentale, Brest, France
}

\section{Introduction}

The efficacy of bio-monitoring programs could be improved through addition of sensitive biomarkers. Among various aspects that could be included in these programs, the immune system is certainly a judicious selection. Indeed, the immune system is considered as a key physiological component in risk assessment, whatever the nature of the contamination. ${ }^{1}$ Moreover, this system is essential towards organism health and interacts intimately with the function of many organs and organ systems. For example, the role of endocrine disruptors, especially Bisphenol-A on the immune system has been previously investigated. $^{2}$ The main role of the immune system is to provide protection to organism against infectious diseases and neoplasic cells. To do so, the immune system is constituted by numerous lymphoid organs as well as cells and a huge number of soluble factors and receptors which render this system highly sophisticated., ${ }^{3,4}$ The efficiency of this complex system is dependent on the optimal balance and communication of these components in organisms. It is well documented that the complexity of the immune system decreases in lower vertebrates and in invertebrate species. The immune defenses of invertebrates, such as mollusks, crustaceans, sponges and oligochaetes rely mainly on non-specific immunity. ${ }^{4}$ Disruption of the immunoregulation in invertebrates could lead to undesirable responses such as immunosuppression. ${ }^{5}$ Although complete elucidation of hematopoiesis in bivalves is not yet fully understood, ${ }^{6,7}$ the effects of environmental contaminants on the immune system of bivalves have been the subject of a rapidly expanding body of literature. ${ }^{4}$ Another key characteristic in bivalves relies in their ability to bioaccumulate chemicals due to their filterfeeding ability and their sedentary life. ${ }^{8}$ Indeed, bivalves are recognized as sentinel species for aquatic ecosystem. ${ }^{9}$ Similar to vertebrates, their immune system is highly vulnerable and among chemicals, we can mention heavy metals and polycyclic aromatic hydrocarbons. ${ }^{10-16}$ This aspect has stimulated great interest because these effects generally occur at levels that are lower than those associated with acute toxicity. ${ }^{3}$ The sensitivity of various immunological responses and the degree to which they agree with host resistance models have been also addressed ${ }^{1,17-19}$ and this work has led to the concept of immunomarkers. ${ }^{20}$ Among immunomarkers, the evaluation of the sensitivity of phagocytosis to a variety of chemicals in bivalves has been under scrutiny since a while because, phagocytic activity is a well conserved function maintained through evolution and therefore is present in all living species. As far as bio-monitoring programs are concerned, phagocytosis of hemocytes from Mya arenaria and Mytilus edulis may represent an ideal immunomarker endpoint

However, the immune system, because of it close interaction with other main physiological systems may also be the target of source of modulation different from environmental pollutants, that should be taking in account as confounding factors. In previous study our group has demonstrated that different habitat conditions such location on the beach and stress related to tides and temperature, can modulate both the immune competence and sensitivity to chemicals. ${ }^{21,22}$ In the present paper, we test in a pilot study the impact on immune competence of seasonal variations and the gender difference in sensitivity to mercury.

\section{Materials and Methods}

\section{Animals and protocols}

Clams and blue mussels were collected at low tide on South shore of the St. Lawrence River, in Metis Bay $\left(48^{\circ} 40^{\prime} \mathrm{N}, 68^{\circ} 00^{\prime} \mathrm{W}\right)$. This is a remote site exempt from any direct sewage outputs and harbor activities. All of the specimens measured between $50-70 \mathrm{~mm}$ in shell length. Upon arrival to the laboratory, clams and mussels were transferred and maintained into different aquaria filled with clean sand with flowing sea water $\left(7^{\circ} \mathrm{C}\right)$ for an acclimation period of two weeks. After acclimation influence of four parameters on the immune response were verify. Experiments were performed twice.
Correspondence: Michel Fournier, Institut National de la Recherche Scientifique-InstitutArmand-Frappier (INRS-IAF) 531 boul. des Prairies, Laval, Quebec, Canada H7V 1 B7.

E-mail: michel.fournier@iaf.inrs.ca

Key words: Mya arenaria, Mytilus edulis, confounding factors, pollutants, immune system.

Conference presentation: part of this paper was presented at the ECOBIM meeting, 2013 May, Montreal, Quebec, Canada.

This work is licensed under a Creative Commons Attribution NonCommercial 3.0 License (CC BYNC 3.0).

(OC) Copright C. Brousseau-Fournier et al., 2013 Licensee PAGEPress, Italy

Journal of Xenobiotics 2013; 3(s1):e2

doi:10.4081/xeno.2013.s1.e2

\section{Temperature}

Animals were collected on June $11^{\text {th }} 2012$ and the temperature at collection time was $7.0^{\circ} \mathrm{C}$. Temperature was gradually raised from 7 to $13^{\circ} \mathrm{C}$ over a period of 6 weeks $(9,11$, $13^{\circ} \mathrm{C}$ ). Animals were left at each new temperature for two weeks before assays.

\section{Population density}

Clams and blue mussels were transferred into common aquaria maintained at $7^{\circ} \mathrm{C}$ at the ratio clam: mussel of $0: 1,1: 1,1: 2,2: 1$, and $1: 0$ for a period of 28 days before assays.

\section{Seasonal variation}

Blue mussels were collected from Metis Bay from June until November, brought back to the laboratory and assays were done immediately upon arrival.

\section{Gender effect}

Hemocytes collected from 40 males and 40 females blue mussels were used in an in vitro exposure to mercuric chloride $\left(\mathrm{HgCl}_{2}\right)$ (Sigma Chemical Company, St. Louis, MO, USA) to verify their sensitivity to toxic. Briefly, individual cell suspensions were distributed in plate $\left(5 \times 10^{5} /\right.$ well) and cells were incubated at final concentrations of $\mathrm{HgCl}_{2}$ ranging from $10^{-9}$ up to $10^{-3}$ for $18 \mathrm{~h}$ before assays.

\section{Collection of hemocytes}

Hemocytes were collected by punction of hemolymph into the adductor muscle using 3.0 $\mathrm{mL}$ syringe and $13 \mathrm{G}$ needle. Cells were then recovered by centrifugation and concentration adjusted as required by the assay.

\section{Cellularity and viability}

A drop of each cell suspension was introduced into a hemocytometer. The number of 
Impact of seasonal variations on phagocytosis

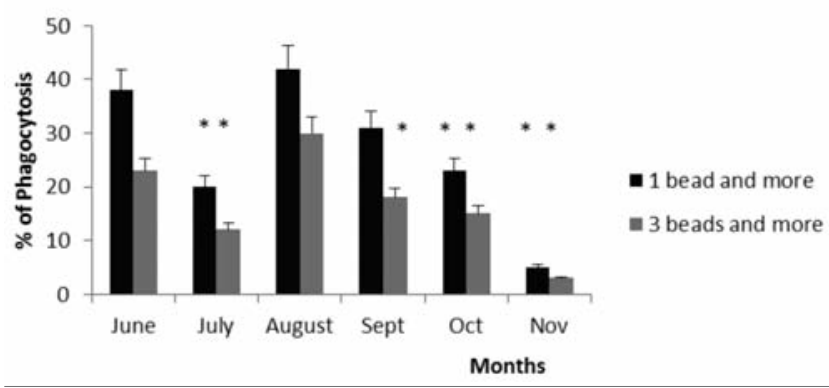

Figure 1. The phagocytic activity of blue mussel is not significantly different between June and August but significantly lower for the other four months.
Gender sensitivity to mercuric chloride

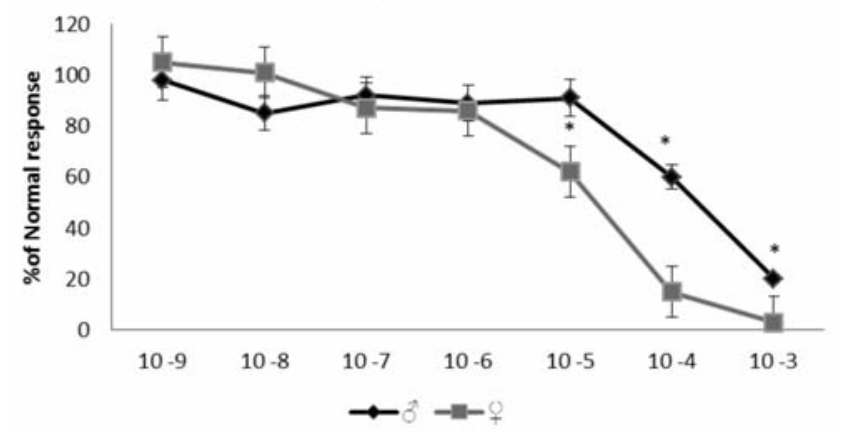

Figure 2. Phagocytic activity of blue mussel, expressed as percent of normal response, shows a higher sensitivity for female than male to mercury with a significant suppression of this function at $10^{-5} \mathrm{M}$ for females and $10^{-4} \mathrm{M}$ for males. cells was determined microscopically. The viability was determined by flow cytometry using propidium iodide. Briefly, $1 \mu \mathrm{L}$ of a $1 \mathrm{mg} \mathrm{mL}^{-1}$ stock solution (Sigma Chemical Company) was added to each cell suspension and flow cytometric acquisition of these suspensions was performed. The results were expressed in percent of viable cells.

\section{Phagocytosis}

Hemocytes were mixed with yellow-green latex FluoSpheres (Molecular Probes Inc., Eugene, OR, USA), at a ratio of 1:30 (hemocytes:beads) in microplates. After an incubation of $18 \mathrm{~h}$ in the dark, the microplates were emptied by inversion. Cells were resuspended and fixed in phosphate buffered saline containing $0.5 \%$ formalin. A FACScan (Becton Dickinson, San Jose, CA, USA) with an air cooled argon laser providing an excitation at $488 \mathrm{~nm}$ was used. Fluorescence emission was collected at $520 \mathrm{~nm}$. Results were expressed in percentage of phagocytic activity ( 1 bead and more), phagocytic efficacy (3 beads and more) or in percentage of normal response.

\section{Statistical analysis}

Results were expressed as mean \pm SD. Each parameter was assessed using two-way analysis of variance (ANOVA), considering the treatment (water temperature ... and metal exposure), the sampling time and their interaction as main factors and the measured parameters as dependent variables. Tukey's multiple comparison tests $(\mathrm{P} \leq 0.05)$ were used where significant differences were detected in the ANOVA (SAS software version 9.1, SAS Institute Inc., Cary, NC, USA).

\section{Results and Discussion}

To our knowledge, only a few studies have investigated so far the effects of changing environmental parameters on the immune responses of bivalves. In this pilot experiment, the range of temperatures tested (7$13^{\circ} \mathrm{C}$ ) did not significantly influence the viability of hemocytes or modify the immune response. However, significant changes for seasonal variations (Figure 1) and gender effects (Figure 2) for phagocytosis activity and efficacy were observed.

For seasonal variations, the results obtained showed that phagocytic activity as well as efficacy was significantly reduced for four time points out of six with a quite important reduction in July as well in November. Results from Crassostrea gigas ${ }^{23}$ showed that phagocytosis index was significantly reduced during spawning in June-July and NovemberDecember. In the present study, we have observed early summer a decrease of the phagocytosis activity which coincide with the spawning. ${ }^{24}$ However, a more dramatic reduction of phagocytosis activity was observed in November, This could be the result of a combined action of spawning and cold water temperature. Though, confirmation of spawning in the fall shall be done.

For gender difference, we have observed that the phagocytic activity in females was significantly reduced when the cells were exposed to $10^{-5} \mathrm{M}$ of mercuric chloride, while significant reduction for males was observed 10 fold higher $\left(10^{-4} \mathrm{M}\right)$. It has already been published similar results in vertebrates, following in vitro incubations of immune cells with heavy metals. ${ }^{25}$ However, to our knowledge, this is the first demonstration of a gender difference to mercury, in bivalves.

In conclusion, this pilot study has reinforced the fact that when environmental studies are designed, special care must be applied in the identification of confounding factors such as temperature, seasonality and gender, which could increase the variability of phagocytosis.

\section{References}

1. Luster MI, Gerberick GI. Immunotoxicology testing: past and future. Meth Mol Biol 2010;598:3-13.

2. Rogers JA, Metz L, Wee Yong V. Endocrine disrupting chemicals and immune responses: A focus on bisphenol-A and its potential mechanisms. Mol Immunol 2013; 4:421-30.

3. Brousseau P, Pillet $S$, Frouin H, Gagné F, Auffret M, Fournier M. Linking immunotoxicity and ecotoxicological effects at higher biological levels. In: Amiard-Triquet C, Amiard JC, eds. Ecological biomarkers: indicators of ecotoxicological effects. Boca Raton: CRC press; 2012. pp 131-146.

4. Brousseau P, Fournier M. Aquatic Immunotoxicology. In: Férard JF and Blaise C, eds. Encyclopedia of aquatic ecotoxicology. Boca Raton: Taylor \& Francis; 2013. pp 79-88.

5. Descotes J. Methods of evaluating immunotoxicity. Expert Opin Drug Metab Toxicol 2006;2:249-59.

6. Johansson MW, Keyser P, Sritunyalucksana K, Söderhäll K. Crustacean haemocytes and haematopoiesis. Aquaculture 2000;191:45-52.

7. Cheng JH, Howland KH. Effects of colchicine and cytochalasin B on chemotaxis of oyster (Crassostrea virginica) hemocytes. J Invertebr Pathol 1982;40:150-2.

8. Philips DJH. The chemistries and environmental fates of trace metals and organochlorines in aquatic ecosystems. Mar Pollut Bull 1995;31:193-200.

9. Auffret M. Bivalves as models for marine immunotoxicology. In: Tryphonas $\mathrm{H}$, Fournier M, Blakley B, Smits JEG, Brousseau P, eds. Investigative immunotoxicology. Boca Raton: Taylor \& Francis; 2005. pp 29-48.

10. Fries CR, Tripp MR. Depression of phago- 
cytosis in Mercenaria following chemical stress. Dev Comp Immunol 1990;4:233-44.

11. Coles JA, Farley SR, Pipe RK. Alteration of the immune response of the common marine mussel Mytilus edulis resulting from exposure to cadmium. Dis Aquat Organ 1995;22:59-65.

12. Brousseau P, Pellerin J, Morin Y, Cyr D, Blakley B, Boermans H, et al. Flow cytometry as a tool to monitor the disturbance of phagocytosis in the clam Mya arenaria hemocytes following in vitro exposure to heavy metals. Toxicology 2000;142:145-56.

13. Fournier M, Pellerin J, Clermont Y, Morin Y, Brousseau P. Effects of in vivo exposure of Mya arenaria to organic and inorganic mercury on phagocytic activity of hemocytes. Toxicology 2001;16:201-11.

14. Auffret M, Mujdzic N, Corporeau C, Moraga D. Xenobiotic-induced immunomodulation in the European flat oyster Ostrea edulis. Mar Environ Res 2002;54: 85-9.

15. Larson KG, Roberson BS, Hetrick FM. Effect of environmental pollutants on the chemiluminescence of hemocytes from the American oyster Crassostrea virginica. Dis Aquat Organ 1989;6:131-6.

16. Sami S, Faisal M, Huggett RJ. Alterations in cytometry characteristics of hemocytes from the American oyster Crassostrea virginica exposed to polycyclic aromatic hydrocarbon (PAH) contaminated environment. Mar Biol 1992;113:247-52.

17. Luster MI, Portier C, Pait DG, White KL Jr, Gennings C, Munson AE, et al. Risk assessment in immunotoxicology. I. Sensitivity and predictability of immune tests. Fundam Appl Toxicol 1992;18:200-10.

18. Luster MI, Pait DG, Portier C, Rosenthal GJ, Germolec DR, Comment CE, Munson $\mathrm{AE}$, et al. Qualitative and quantitative experimental models to aid in risk assessment for immunotoxicology. Toxicol Letters 1992;64/65:71-8.

19. Luster MI, Portier C, Pait DG, Rosenthal GJ, Germolec DR, Corsini E, et al. Risk assessment in immunotoxicology. II. Relationships between immune and host resistance tests. Fundam Appl Toxicol 1993:21:71-82.

20. Pillet S, Nicolas JM. Biomarkers of immunotoxic effects in the context of environmental risk assessment. In: Tryphonas H, Fournier M, Blakley BR, Smits JEG, and Brousseau P, eds. Investigative immunology. Boca Raton: Taylor \& Francis; 2005. pp 451-76.

21. Alix G, Beaudry A, Brousseau-Fournier C, Fortier M, Auffret M, Fournier M, et al.
Increase sensitivity to metals of hemocytes obtained from Mya arenaria collected at different distances from the shore. $\mathrm{J}$ Xenobiotics 2013;3(s1):e11.

22. Beaudry A, Brousseau-Fournier C, Alix G, Fortier M, Auffret M, Brousseau P, et al. Influence of tidal stress on the immunocompetence of hemocytes in soft-shell clam (Mya arenaria). J Xenobiotics 2013;3(s1):e13.

23. Duchemin M, Fournier M, Auffret M. Seasonal variations of immune parameters in diploid and triploid Pacific oysters, Crassostrea gigas (Thunberg). Aquaculture 2007;264:73-81.

24. Lemaire N, Pellerin J, Fournier M, Girault L, Tamigneau E, Cartier S, et al. Seasonal variations of physiological parameters in the blue mussel mytilus spp. from farm sites of eastern Quebec. Aquaculture 2006;261:729-51.

25. Fournier M, Blakley BR, Boermans HJ, Brousseau P. Toxicological considerations: making the connection between toxicologic and immunotoxicologic studies as these relate to human and ecosystem In: Tryphonas H, Fournier M, Blakley B, Smits JEG, Brousseau P, eds. Investigative immunotoxicology. Boca Raton: Taylor \& Francis; 2005. pp 479-493. 